\title{
Improving Green Marketing Performance: Study Case on Natural Color Batik SME's in Central Java
}

\author{
$1^{\text {st }}$ Cicik Harini ${ }^{1}, 2^{\text {nd }}$ Sony Heru Priyanto ${ }^{2}, 3^{\text {rd }}$ John J.O.I Ihalauw, $4^{\text {th }}$ Roos Kities Andadari \\ \{cicikharini@yahoo.co.id ${ }^{1}$, soneid@yahoo.com ${ }^{2}$, \\ ihalauw@staff.uksw.edu ${ }^{3}$, roos.kities@staff.uksw.edu $\left.{ }^{4}\right\}$ \\ Pandanaran University, Jl. Banjarsari Barat No. 1, Semarang ${ }^{1}$ \\ Universitas Kristen Satya Wacana, J1. Diponegoro No.52-60, Salatiga ${ }^{2,3,4}$
}

\begin{abstract}
Marketing performance is a managerial perception of a company's ability to achieve market share, sales growth, profitability, and customer loyalty. Based on research gaps and empirical phenomena, the problem of this study is to explain the relationship between the capabilities of ecological entrepreneurs and ecological marketing to green marketing performance. This study aims to analyze the effect of ecological entrepreneurial capabilities and ecological marketing to improving green marketing performance. The study was conducted on SMEs in natural color batik in Central Java. The sampling method used nonprobability sampling with judgment sampling technique. The number of respondents is 120 people. Data retrieval is done by interviewing techniques directly to respondents using a questionnaire. The method of analysis uses SEM-PLS. The results of the analysis show that the performance of ecological entrepreneurs and ecological marketing affect green marketing performance.
\end{abstract}

Keywords: Green Marketing Performance, Capability of Ecological Entrepreneurs, Ecological Marketing.

\section{Introduction}

Environmentalism that is manifested in sustainability is described as increasing concern about environmental degradation caused by employer's selfishness in pursuing economic growth [1]. Therefore, the idea of sustainable development must run parallel, along with efforts to achieve economic growth, and will ensure effective protection of the environment globally. The discussion about the relationship between Social, Economic, and Environmental [2] continues to grow. Ecopreneurship is an entrepreneur who runs a business based on the principle of sustainability [3] by linking social, environmental and economic problems to the sustainability of business activities in the future.

Ecological entrepreneurs aim to transform the business sector through challenging social and ethical norms. Unlike entrepreneurs in general, ecopreneurship is not motivated solely for profit, but rather a desire to improve the world through pre-existing environmentally friendly values and the potential to be a leader in changing the norms of consumer behavior towards those who like sustainability and the environment [4]. The capability of ecological entrepreneurs shows that entrepreneurship instills environmentalism in a social context [5].

As the global market continues to grow, the pillars of sustainability (i.e., environment, economy, and social justice) are increasing, as part of marketing decision making [6]. Green marketing strategies will follow consumer consumption concerns [7], and increasingly 
develop to improve green marketing performance. Eco-batik is a batik that is based on clean production, which is a preventive, integrated and continuously applied environmental management strategy for every activity from upstream to downstream related to production processes, products and services to improve the efficiency of the use of natural resources, preventing the occurrence of environmental pollution and reducing the formation of waste at its source so as to minimize risks of human health and safety and environmental damage. To develop eco-batik to be widely known by the community and to maintain business continuity, ecological marketing is needed which is expected to improve the performance of green marketing.

The results of this study are expected to provide theoretical benefits to enrich the study of knowledge about efforts to improve the performance of green marketing through the capabilities of ecological entrepreneurs and ecological marketing. The practical benefit of this research is to provide understanding for batik SMEs to develop batik business without polluting the environment. Regulators related to SMEs can also take appropriate policies to enhance the capabilities of ecological entrepreneurs in determining the right marketing strategy.

\section{Capability of Ecological Entrepreneurs}

Ecological entrepreneurs (Ecopreneurship) have developed since 1990s, where the discourse of ecological modernization began to dominate environmental and energy politics throughout the world by making various clean and green technological regulations [14], [15]. Ecopreneurship is entrepreneurship that is environmentally vision in carrying out its business. Integrating attention to social and environmental issues into economic actions is related to the responsibility for sustainable development including the sustainability of business activities in the future [16]. To achieve sustainable success, ecological entrepreneurs must be able to fulfill what is called the 'triple-bottom-line' [17], namely achieving economic prosperity, paying attention to the quality environment (environmental quality), and pay attention to social justice (social equity). They not only make profits, but they also have to be responsible for social and environmental interests simultaneously. Integrating these dimensions, the capabilities of environmentally friendly entrepreneurs include clean-growth business, social care (sociallyaware business), and environmentally save businesses.

The hypothesis in this research:

H1: Capability of ecological entrepreneurs influences Green Marketing Performance.

\section{Ecological Marketing}

The concept of ecological marketing as a managerial process holds the responsibility of identifying, satisfying and anticipating the needs of customers and society profitably and sustainably [18]. Ecological marketing as a marketing activity that recognizes environmental concerns as responsibility for developing business and developing opportunities. In synthesis, ecological marketing refers to promoting and advertising products with ecological characteristics.

Ecologically oriented marketing, basically involves a change in mentality by increasing environmental awareness and concepts that are deeply rooted in business culture. Another problem that must be considered is that there are several problems with the use of ecological marketing and its concepts. For example, high costs and government policies, but companies are required to gain a competitive advantage by using marketing strategies and ecological marketing models based on human, knowledge, and sustainability. Baran and Popescu [13] suggest that ecological marketing is conducting marketing activities that include product improvement, pricing, promotion, and placement, to minimize the impact on the environment.

The hypothesis in this research: 
H2: Ecological Marketing influences Green Marketing Performance.

\section{Green Marketing Performance}

Marketing performance is a measure of the results achieved by a company from marketing activities or company operations [8], in the form of: market measurements, customer value perceptions and benefits derived from these marketing activities. Marketing performance can be reflected by the acquisition of market share, market share growth, sales growth, profit growth and shareholder value [9]. Measure marketing performance from how the company can generate profits from each customer, and the position of the company in competition [10]. The inability of marketing managers to determine the costs incurred in contributing to the increase in the level of corporate profits is caused by the difficulty of designing indicators to measure marketing performance.

In empirical research, James (1994) classifies environmental performance into processes, resource consumption, emissions and waste, efficiency, risk, ecological impact, consumer perceptions and actions related to financial impacts. Measuring the environmental performance of companies more coherently with a more comprehensive derivative of the company's environmental theory [11]. The environmental impact of the company on performance results, including profitability, market share, and customer loyalty [12].

The concept of green marketing and the idea of healthy earth and a successful marketing strategy have been reviewed by previous researchers. Green marketing defines the potential role of organizations, consumers, and governments and how these groups influence environmental factors through the marketing process [13]. Marketers must be able to influence consumer behavior towards environmentally friendly products and effectively educate them. Green marketing provides guidance and the consequences of failure, so measurements are needed to determine how much green marketing performance has been achieved by marketers. From the description above, the performance of green marketing is always related to fulfilling expectations, basically, it can be understood as the extent to which companies fulfill their stakeholders' expectations regarding environmental responsibility [11].

H3: Capability of Ecological Entrepreneurs influences Green Marketing Performance by being moderated Ecological Marketing

\section{Methodology}

\subsection{Research Design}

This research is included in the type of explanatory research with a quantitative approach to look for explanations in the form of causal relationships between several variables through testing one hypothesis with another variable. The population in this study is the business of natural color batik in the Central Java Region, while the sample selection uses nonprobability sampling techniques with judgment sampling techniques, namely the technique of determining the sample with certain considerations on the business of natural color batik and natural color batik worker incorporated in SMEs, so 120 samples are set. Data sources came from businesses of natural color batik and natural color batik worker in SMEs and data collection was done through questionnaires to respondents. 


\subsection{Analysis Method}

Data were collected by using questionnaires first tested for reliability and validity. Testing is to know the consistency and accuracy of data collected from the use of instruments. Further, the hypothesis is tested using path analysis or Structural Equation Modeling analysis. The hypothesis is answered by estimating the PLS parameters as follows :

1. Assessing the outer model and measurement model. The Outer Model defines how each indicator block corresponds to its latent variable. The measurement model or Outer model with reflexive indicator is evacuated with Convergent and Discriminant Validity of the indicator and Composite reliability for the indicator block.

2. Assess the Inner Model or Structural. The inner model describes the relationship between latent variables based on Substantive theory. Inner model wants to see the relationship between construct and significance value and R-Square value. Relationship between constructs can be seen from the estimation Coefficient path parameter model structural. The structural model is evaluated by using R-Square for dependent constructs, Stone-Geisser Q-square test for Predictive relevance and test and the significance of structural path parameter coefficients.

\section{Results and Discussion}

\subsection{Analysis of Outer Model (Measurement Model)}

The outer model analysis is conducted to ensure that the indicators used are feasible (valid and reliable) to be used as a measure of the variables studied. The Outer model defines the relationship between latent variables and their indicators. Outer model analysis can be seen from several indicators, namely convergent validity, discriminant validity, and unidimensionality.

\subsubsection{Convergent Validity}

The value of discriminant validity is the value of the loading factor in the latent variable with its indicators. The value of the loading factor is expected to be 0.70 , but a value between 0.50 can still be tolerated as long as the model is still in the development stage. The results of data processing indicate a loading factor greater than 0.70 which means all indicators are valid.

In addition to the value of the loading factor, convergent validity can also be seen from the Average Variance Extracted (AVE). The expected AVE value is $>0.5$. In the study of AVE values, each construct is above 0.5 . Therefore there is no problem of convergent validity in the model under test. The results of the data processing show the AVE value of construct $\mathrm{X}$ $=0.569, \mathrm{Y}=0.556, \mathrm{Z}=0.533$.

\subsubsection{Discriminant validity can be seen from the value of cross loading factor.}

If the correlation of the indicator with its construct has a higher value than the correlation of the indicator with another construct, it is said that the construct has a high discriminant validity. The correlation of the indicator with the construct has higher value than the correlation of the indicator with other constructs. Therefore, the construct has high discriminant validity. 


\subsubsection{Unidimensionality Test}

Unidimensionality is performed using composite reliability and Cronbach alpha indicators. Data that has a value of composite reliability and Cronbach alpha> 0.7 means that the data has a value of reliability or high reliability. The results of the data processing show the Composite Reliability construct $\mathrm{X}=0.868, \mathrm{Y}=0.907, \mathrm{Z}=0.814$ and Cronbach Alpha construct $\mathrm{X}=0.811, \mathrm{Y}=0.881, \mathrm{Z}=0.702$, it is known that all constructs have a high degree of reliability, because of the value of composite reliability and Cronbach alpha $>0.7$.

\subsection{Inner Model Analysis (Structural Model).}

Inner model describes the relationship between latent variables based on substantive theory. This analysis is done to ensure that structural models are built robust and accurate. Inner model evaluation can be seen from several indicators namely Coefficient of Determination (R2). The value of $\mathrm{R} 2$ is the coefficient of determination in endogenous constructs. The results of the data processing show the value (R2) of the Endogenous Variables $\mathrm{Y}=0.252$ and $\mathrm{Z}=0.634$, it's mean :

a. Green marketing performance is explained by changes in the capability of Ecological Entrepreneurs of $25,2 \%$, while $74.8 \%$ is explained by other variables not examined.

b. Green marketing performance is explained by changes in ecological marketing of $63.4 \%$, while $36.4 \%$ is explained by other variables not examined.

\subsection{Hypothesis Testing}

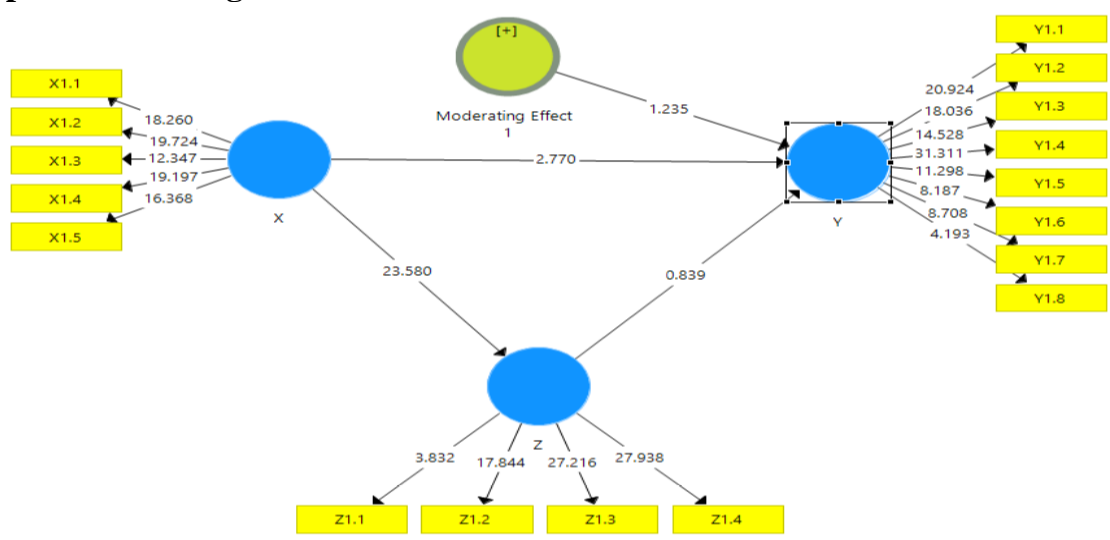

Figure 1. Model of Research

Source: Primary data processed, 2019

H1: Testing the Capability of Ecological Entrepreneurs towards Green Marketing Performance

From the results of testing, the influence of ecological entrepreneurs capability on the performance of green marketing produces a standardized parameter coefficient of 0.406 with a $\mathrm{CR}$ value of 3.401 which is above the requirements of $C R \geq 2.00$ and probability values 0,023 $<0.05$, so it can be concluded that the variable capability of ecological entrepreneurs positively significant effect on green marketing performance.

H2: Ecological Marketing Testing towards Green Marketing Performance

From the results of testing the effect of ecological marketing towards the performance of green marketing produces a standardized parameter coefficient of 0.219 with a CR value of 2.052 which is above the requirements of $C R \geq 2.00$ and probability values $0,023<0.05$, so it can be concluded that ecological marketing variables have a significant effect positive for green marketing performance. 
H3 : Testing the Capability of Ecological Entrepreneurs towards Green Marketing Performance by being moderated Ecological Marketing

The capability of ecological entrepreneurs directly influences the performance of green marketing with a parameter coefficient of 2.770 and significant at 0.154 . Ecological marketing has a direct effect on the performance of green marketing with a parameter coefficient of 0.839 and significant at 0.152 . The interaction variable between ecological entrepreneur capability and ecological marketing has a significant effect on the performance of green marketing with the parameter coefficient value 1.235 with a probability of 0.059 . Therefore, it can be concluded that the ecological marketing variable is a moderating variable or variable that moderates the relationship between ecological capability and green marketing performance.

\section{Conclusion}

Empirically the performance of green marketing is influenced by the capabilities of ecological entrepreneurs, which means that the performance of green marketing is an implication of marketing activities that have been developed by ecological entrepreneurs. The results of this study are following the opinion of Bowers [19] which states that performance measurement covers the whole of business performance, responsibility towards the social community and the surrounding environment. To obtain performance excellence regarding caring for the environment becomes an integral and inseparable part of the overall performance measurement framework. Ecological entrepreneurs must have capabilities that meet the criteria of clean growth, social care, and business activities that are environmentally friendly, and have a work ethic and skills [20].

Ecological marketing has a very important role to play in achieving green marketing performance, so that ecological business people can maintain and continue to improve their business. The results of this study are not in line with the findings of Esakki's research (2017) assuming that green marketing does not generate direct profits, so companies must diligently implement a process to educate consumers about the benefits of green marketing and environmental threats. Companies that are committed to the principles of environmental sustainability in their operations seek to use renewable resources and try to minimize the negative environmental impacts of their activities. Companies must avoid "green myopia", meaning there is no point in producing truly green goods in various aspects that do not meet consumer needs.

\subsection{Research Limitations}

The research was only conducted in the Central Java region due to limited time and funding sources, it is hoped that this research can be developed into other regions so that it can motivate synthetic color SMEs to switch to SMEs of natural color batik.

\subsection{Recommendation}

For other researchers who are interested in developing this research, it is expected to analyze other variables and conduct in-depth interviews and directed to natural color batik entrepreneurs, so that wider information can be obtained to obtain information that can improve ecological capabilities and more appropriate ecological marketing strategies to improve the performance of green marketing facing global market competition. 
Acknowledgements. The writing of this article has been assisted by academic writing workhop on the $3^{\text {rd }}$ International Conference on Gender Equality and Ecological Justice with the theme, Universitas Kristen Satya Wacana, Central Java, Indonesia.

\section{References}

[1] J. C. Anderson and D. W. Gerbing, "Structural Equation Modeling in Practice: A Review and Recommended Two-Step Approach," Psychol. Bull., 1988.

[2] K. Tienhaara, "Varieties of green capitalism: economy and environment in the wake of the global financial crisis," Env. Polit., 2014.

[3] B. Cohen and M. I. Winn, "Market imperfections, opportunity and sustainable entrepreneurship," J. Bus. Ventur., 2007.

[4] K. Kearins and E. Collins, "Making Sense of Ecopreneurs' Decisions to Sell Up," Bus. Strateg. Environ., 2012.

[5] J. Kirkwood and S. Walton, "What motivates ecopreneurs to start businesses?," Int. J. Entrep. Behav. Res., 2010.

[6] M. H. Huang and R. T. Rust, "Sustainability and consumption," J. Acad. Mark. Sci., 2011.

[7] S. Sheng, K. Z. Zhou, and J. J. Li, "The Effects of Business and Political Ties on Firm Performance: Evidence from China," J. Mark., 2010.

[8] A. E. Clark, E. Diener, Y. Georgellis, and R. E. Lucas, "Lags and leads in life satisfaction: A test of the baseline hypothesis," Econ. J., 2008.

[9] R. Shaw, "Relationship Marketing: Exploring Relational Strategies in Marketing," Interact. Mark., 2002.

[10] B. N. Anand and T. Khanna, "Do Firms Leant to Create Value? The Case of Allainces," Strateg. Manag. J., 2000.

[11] A. B. Carroll, "A Commentary and an Overview of Key Questions on Corporate Social Performance Measurement," Bus. Soc., 2000.

[12] S. B. Banerjee, E. S. Iyer, and R. K. Kashyap, "Corporate Environmentalism: Antecedents and Influence of Industry Type," J. Mark., 2003.

[13] B. Tamer and P. Catalin, "Generation Z Attitudes Toward Green Marketing: a Cross Country and Gender Analysis.," Ann. "Constantin Brancusi” Univ. Targu-Jiu. Econ. Ser., 2016.

[14] F. H. Buttel and M. A. Hajer, "The Politics of Environmental Discourse: Ecological Modernization and the Policy Process.," Soc. Forces, 2006.

[15] M. Hultman and A. Yaras, "The socio-technological history of hydrogen and fuel cells in Sweden 1978-2005; Mapping the innovation trajectory," Int. J. Hydrogen Energy, 2012.

[16] D. Kainrath, "Ecopreneurship in Theory and Practice - A Proposed Emerging Framework for Ecopreneurship," Umeå Sch. Bus., 2009.

[17] D. Y. Choi and E. R. Gray, "Socially responsible entrepreneurs: What do they do to create and build their companies?," Bus. Horiz., 2008.

[18] J. Kärnä, E. Hansen, and H. Juslin, "Social responsibility in environmental marketing planning," Eur. J. Mark., 2003.

[19] J. S. Bowers, "Does masked and unmasked priming reflect Bayesian inference as implemented in the Bayesian Reader?," European Journal of Cognitive Psychology. 2010.

[20] E. D. Wulandari, "Pengaruh Inovasi Kelembagaan Pada Pengembangan Klaster Batik Laweyan Kota Surakarta,” J. Wil. dan Lingkung., 2016. 
